\title{
Women without a Voice: The Paradox of Silence in the Works of Sandra Cisneros, Shashi Deshpande and Azar Nafisi
}

\author{
Sharon K. Wilson \\ Fort Hays State University

\section{Pelgy Vaz \\ Fort Hays State University}

Women of every culture face a similar problem: loss of voice. Their lives are permeated with silence. Whether their silence results from a patriarchal society that prohibits women from asserting their identity or from a social expectation of gender roles that confine women to an expressive domain-submissive, nurturing, passive, and domestic-rather than an instrumental role where men are dominant, affective and aggressive-women share the common bond of a debilitating silence. Maria Racine, in her analysis of Janie in Zora Neale Hurston's Their Eyes Were Watching God, reaffirms the pervasiveness of this bond: "For women, silence has crossed every racial and cultural boundary" (283). Indeed, Elaine Mar, a Chinese-American writer, in her memoir, Paper Daughter, 
elucidates the implications of silence for women, "Like Mother I was learning to disappear. Frequently, I sought refuge with her in the basement room, in the silence of empty spaces. But I was also learning to vanish in full sight of others, retreating into myself when physical flight wasn't possible. My voice withered. Silent desire parched my throat" (48). Silence and loss of voice debilitate and stifle women, as they are forced to sublimate their identity in order to survive in their worlds.

While many writers discuss the issue of silence, we intend to focus on the motif of silence and its impact on three characters, individuals: Esperanza in House on Mango Street by Sandra Cisneros, Ajji in My Beloved Charioteer by Shashi Deshpande, and Azar Nafisi in Reading Lolita in Tehran by Azar Nafisi. These authors write about women who have been socialized in a traditional, patriarchal society where men generally make decisions, have hegemonic control, and are usually physically, psychologically, or emotionally aggressive. In such an environment, women lack the opportunity and confidence to assert themselves or have some measure of control over their environment or their lives in order to establish their autonomy, and are, therefore, victimized by what Paulo Freire terms the "culture of silence" (13). If they confront instead of acquiescing to the traditional paradigm, their actions, at a minimum, are curtailed, or as is the case with Nafisi, completely forbidden. Ironically, however, women's loss of voice serves a twofold function.

While socio-cultural restrictions compromise their ability to find a voice and thus confine and marginalize Esperanza, Ajji, and Nafisi, these restrictions also provide them with the impetus to assert and redefine themselves in a manner similar to the mythological Phoenix. Just as the Phoenix builds a pyre, burns itself to ashes, and then reemerges, renewed and reborn, so too do these women undergo the ritualistic death-rebirth cycle. Their silence evokes a sense of independence and eventually fosters, 
usually as a result of a domestic crisis, an epiphany in which they find and assert their voice, breaking through the silence. We will examine the ways in which these female characters are controlled by men, the symbols through which that control is expressed, and the strength these women find to transcend cultural, familial and social repression, sometimes at a tremendous personal cost.

While not all women may experience such a traditional upbringing, the fact that these experiences transcend cultural boundaries makes an important contribution to comparative cultural and gender literary analysis. These characters, developed by their culturally diverse authors, are separated by culture, time, and history, yet they share universal conflicts in the quest to discover their identity. The theme of the quest, also referred to as a form of the death-rebirth archetype, according to Joseph Campbell in Hero with a Thousand Faces, consists of at least four major phases: heading the call to adventure, facing the unknown, encountering conflicts and receiving concrete or symbolic rewards, and eventually "returning to the community" ( Chapter 1). Campbell emphasizes the flexibility of these stages: some may be absent while others may be more fully developed and explored. The central characters in the works of Cisneros, Deshpande, and Nafisi evolve through these universal stages of the death-rebirth archetype, and--individually, as an unexpected function of their cultural sublimation--acquire the strength to find their voices and their identities, in spite of, and ironically because of, the repression they experience.

Not surprisingly, the home or house is the central source of alienation, confinement, and sometimes imprisonment for all of these women. Thus, transcending the physical and emotional boundaries of "home" becomes a crucial factor in crossing the threshold into the unknown and facing various obstacles before they can discover the strength to assert their identities. Esperanza, the main 
character in The House on Mango Street, dreams of having a "real" house, "with running water and pipes that worked . . . with real stairs, not hallway stairs, but stairs inside like the houses on T.V." (4). When her family finally gets their first house, however, the reality of their poverty shatters her illusion. Instead of creating a sense of pride and stability within her, her house has "small tight steps in front and windows so small you'd think they were holding their breath" (4). This dilapidated house engenders within Esperanza a sense of shame and embarrassment, which is made apparent, when one of the nuns from her grade school stops to look at Esperanza's house and says, "You live there' "? There. The way she said it made me feel like nothing" (5). When the nun criticizes Esperanza's house, she is, in effect criticizing and demeaning Esperanza, whose house is an extension of her own identity. By pointing to this dilapidated house, she points to herself, revealing her own poverty and shame (Olivares 215-216).

Esperanza's feeling of nothingness is reinforced by the images of "tight steps" and "small windows," which symbolize not only her shame at her impoverished life, but also the physical confinement she experiences as a result of her gender. Thus, the house becomes a metaphor for the cultural and economic limits imposed on marginalized women. The image of the window defines the position of women in her culture: imprisoned, viewing life rather than participating in it.

Esperanza's grandmother further epitomizes the impact the patriarchal society has on women. When her grandmother was young, she was described as a vibrant, "horse woman," a strong and independent woman. However, her strength "which is supposed to be bad luck if you're born a female [because] ... the Mexicans don't like their women strong" is eroded when she marries. (10). Slowly, but inevitably, stricture and confinement impact Esperanza's grandmother to the point where she becomes a non-entity, someone who 
"looks out the window her whole life the way that so many women sit their sadness on an elbow" (11). Her silent acquiescence foreshadows the reality many young Latino women experience. Erlinda Gonzales-Berry and Tey Diana Rebolledo clarify the position of women in Latino cultures: "The female . . . is carefully schooled to function in society, to lose her freedom and her sense of individuality in order to become a loving wife and mother. She thus integrates her destiny with that of a man. . . Thus, rather than achieving maturity, young women . . . are led down the path to second infancy" (109-10). With her options limited, Esperanza's grandmother retreats within herself and withdraws from life.

Many of Esperanza's female friends experience the same sense of confinement and loss of voice as her grandmother. Her friend Rafaela, for example, is still young, but she is "getting old from leaning out the window so much" (Cisneros 79). Her husband locks her in the house because she is too beautiful and he fears she will run away, so she "leans out the window and leans on her elbow" (79), becoming a prisoner in her own home. Rafaela dreams of having hair like Rapunzel's, so a prince will climb her hair and rescue her from her "empty room" (79). Unable to voice her dreams, take control over her own life, and escape her environment, she settles and remains a passive victim of her illusion and dreams. She, like Marin, another young woman, is "waiting for a car to stop, a star to fall, someone to change her life" (27). Neither asserts control over their destiny, and thus reinforces the second infancy concept. Another friend, Sally gets married too young to escape an abusive father, but she merely changes one prison for another. Her husband, like her father, wants complete control over her, so even though she has her own "new house," he doesn't allow her to "look out the window" (102). Even though she seems happy because she can buy material objects, she can only buy them when "he gives her money," another way by which he asserts his dominance (102). Because she fears her husband, she 
never leaves her new home; she never talks to her friends unless her husband is at work. Instead, she looks at the new "things they own," none of which make her happy (102). Her future, like her past, is bleak: no windows, no voice, and no friends.

Unlike her peers and her grandmother, or maybe in part because of her peers and her grandmother, Esperanza makes a conscious decision "not to inherit her grandmother's" place by the window, even though she inherited her name (11), a fact she wishes to change. She wants to reinvent herself by baptizing herself with a new name that expresses her true self, "something like Zeze the X will do" (11). She wants a name that defines her true nature. She has witnessed the repressive, shallow existence of her grandmother and her peers and "refuses to sacrifice her gender to a patriarchic society and undertakes a personal quest to liberate herself from the gender constraints of her culture" (Olivares 213). She acts on her desires: she begins a quiet war, leaving the "table like a man without putting back the chair or picking up the plate" (Cisneros 89). She is no longer prey to her oppression and silence. In fact, according to Freire, she is emerging from her oppression and turning upon it, a step she achieves by "reflection and action upon the world in order to transform it" (36). This act of defiance, although perhaps minor in terms of physical action, is a major step in her actualization, rebirth process, especially considering she has few, if any, role models to teach her such an assertive behavior. Her friends resolve conflicts by quietly acquiescing, while Esperanza resolves her conflict by asserting her voice. Therefore, her aggressive action crosses the threshold into the unknown. Her new-found strength is symbolized by comparing herself to trees whose "strength is secret . . . who grow despite the concrete [and] do not forget to reach" (74-75). Just as the trees survive despite their constrictive environment, so, too, will Esperanza survive and triumph over an environment that is hostile to the 
acquisition of independence and strength.

By recognizing her internal strength, she overcomes obstacles that endanger her independence. At this point, Esperanza is consciously and internally reinventing herself, a process that is symbolized through her desire to have that "real house" she dreamed of having: "not a man's house. Not a daddy's. A house all my own . . . a house as quiet as snow, a space for myself to go, clean as paper before a poem" (108). Her epiphany is "quiet, thoughtful, and strong: I am too strong for [Mango Street] to keep me here forever"(110). Her strength and empowerment are evident in the final stage of the quest, the return or redemption, which occurs toward the conclusion of the novel with the realization that her friends and neighbors will not know she has "gone away to come back" (110). A crucial aspect of the transformation can now occur; once she becomes empowered, she can return to Mango, "For the ones who cannot [get] out" (110). Accepting and acknowledging individual responsibility to the community, according to Campbell, is indispensable to the "continuous circulation of spiritual energy into the world" (Hero 36). Yet, according to Campbell, the last stage is the most difficult phase because the heroes may not be able to sustain their new-found knowledge, or they may face derision from the community (36-37). Because Esperanza has acknowledged her responsibilities to the community as an integral part of developing her autonomous self, she will be able to sustain her voice and continue on her quest.

Metaphorical and physical confinement in the home is also an obstacle faced by Ajji, the grandmother in My Beloved Charioteer. She, like many of the female protagonists in Deshpande's fiction, is "an emotionally cloistered woman who struggles to shed her inhibitions and her cloistered self" (Dinesh 196). However, in Ajji's case, confinement is self imposed out of a sense of fear, duty, and ingrained cultural obligation to her dead husband. Such a sense of duty and obligation is 
manifested and perpetuated generationally in patriarchal cultures. In India, "Both men and women are socialized into accepting the male's superiority" (Atrey and Kirpal 7). Because she no longer has to subordinate herself, a manifestation of silence, to her husband's wishes or cope with her husband's physical, psychological, and emotional abuse, Ajji feels safe and is comforted by the silence that now permeates her world. She describes it as a "friendly silence filled with the ghosts of so many voices" in her life, who return to her and keep her company when she is alone (Deshpande 373). She enjoys her life: free from tension, pain and criticism. Even though the silence comforts her, it is an artificial silence, isolating her from the life-affirming community. According to A.K. Awasthi, if a character does not feel a need for self-assessment, he or she may come to feel a love for and acceptance of illusion (98). She subconsciously accepts the illusion of peace and contentment, and the self-imposed silence that accompanies such an illusion. Because she does not acknowledge his continued control over her, "Habits of obedience die harder than any other" (373), she is still a victim, the same passive victim she was with her husband. Before she can establish her autonomy and find her voice, she must be able to confront her past. Her continued victimization is symbolized through her husband's room. Even though he has been dead for seven years, Ajji keeps his room immaculately clean; it is unchanged, just as his psychological control over her is unchanged.

Often typical of women living in compromising conditions, Ajji does not recognize her isolation or her victimization. She feels "bound by tradition and myth to keep her silence intact" (Dinesh 198) until her daughter, Aarti and her granddaughter, Priti move into her home. With Aarti comes a different type of silence, a repressive silence, and an "infinity of bitterness" (Deshpande 375) over what she perceives to be the unfairness of life because she has lost everyone she has ever loved, her father and husband. Wallowing in self-pity, "Isn't it 
gloomy here? The right atmosphere for a pair of desolate widows" (374). Ajji recognizes the oppression Aarti brings with her," Aarti turns "everyone's happiness into a wrong" (375). As a result of her self-absorption, she stifles any type of communication with her mother, and subconsciously blames her mother for her losses and for her emotional death.

Lacking the moral courage to confront her daughter in the much the same way she was afraid to confront her husband, "I have no courage to speak" (375), Ajji allows her daughter to suffocate her happiness by controlling her voice. Her self-deprecation is a typical characteristic of people who are oppressed and results from internalizing the negative opinions the oppressor has of them. If they constantly "hear that they are good for nothing, know nothing . . . in the end, they become convinced of their own unfitness" (Freire 49). In fact, she even blames herself for Aarti's emotional withdrawal from life: "If my daughter is so empty that she can hate people who are happy, the fault is, to some extent, mine" (375). Not until Ajji begins to realize the impact Aarti's emotional callousness is having on her granddaughter, who is afraid to speak to her mother and wants to sleep in her grandmother's room at night, does she become more concerned about her granddaughter's feelings than what she perceives as her own inadequacy, "I have never known how to win anyone's love” (375). Priti has awakened new life in Ajji and has brought her a happiness she has never known, "the day is full of meaning. I wait . . . eagerly for her to return from school. I don't know who is happier, she or I"(375). On the other hand, when Priti leaves for school, a "silence settles on the house" enveloping Ajji and bringing with it a death-like pall and a safe retreat into her voiceless home (372), and she succumbs to a disassociation from herself and society. Thus, she remains passive and alienated.

Eventually, Ajji's happiness and love for Priti prompt her to find the courage to confront not only Aarti but also 
her dead husband. In fact, one could argue that Ajji's evolution occurs because of her relationship with Priti. Priti is the catalyst by which Ajji finds the strength to end the cycle of silence. She had, until Priti arrival, suffered from a "symbolic deficiency," lack of voice (Hero 37).

Ironically, her husband's room offers her the opportunity to find her voice, rebel against her oppressor, and break the pervasive silence that threatens to destroy her home and granddaughter. Aarti, her daughter, provides her with the stimulus to confront her ghosts and usurp her husband's power over her when Aarti, who is sitting in her father's room, accidentally knocks over her father's photograph. When the photograph falls "face down,". . . The glass . . . cracked. Long splinters of glass lie on the floor," making the photo look "somehow naked," his importance in controlling and directing her life symbolically begins to shatter. Ajji has crossed the first threshold and, and although somewhat hesitant, tells her daughter she does not want to ever see the photograph again, “I don't want it. Let it go" (376). The "it" in her references seems to symbolize his continued authority over her and his presence in the room. Even as she becomes assertive, she still wonders timorously if her husband can hear her. Again, her fear results from internalizing the image of the oppressor and adopting his guidelines. Therefore, she is still apprehensive about speaking and afraid of the freedom that may result from her assertion (Freire 31). But she refuses to acquiesce to her fears and argues that she has let her husband go. Once she is able to articulate the words, "I let him go," she achieves an epiphany, a sudden revelation that she kept a room immaculate for a man who didn't value her and stifled her voice (376). Like Esperanza, once she crosses the first threshold, she cannot turn back. She is able to articulate her new-found strength and break the artificial silence that has permeated her life. With each assertion, she affirms the reality of emotional abuse and neglect she endured, "I know he didn't like tears. And so, 
when your baby brothers died, I wept alone and in secret. And at night . . . I scarcely dared to breathe, I was so terrified of disturbing him" (376). By confronting her abuse and shattering the illusions under which Aarti has been living, Ajji gains the courage to dispel not only her demons but perhaps her daughter's as well. Both women were voiceless-- existing, not living--without substantial control over their lives or their future. While Aarti has not experienced the denigration her mother has, she has lost her voice, her control over her future with the death of her husband. She, like her mother, has been a victim of the patriarchal society. Daughters are closer to their fathers because it is the mother's responsibilities to "impose restrictions on her and prepare her for a harsher future as part of the process of socialization" (Atrey and Kirpal 78). Thus, because she is conditioned in this process, Aarti loves her father and resents her mother.

However much her daughter tries to avoid the truth about her father, "Don't tell me. Don't," her father's control is diminishing: "With each negative [Aarti] bangs the photograph she still holds in her hands and the glass splinters again and again" (376-77). Again the image of the shattering glass foreshadows the disintegration of his control over Ajji. Now that he is "totally exposed to both of [them]," Ajji shatters the artificial reality she has created. She feels a sense of self-empowerment she has never experienced before; she is learning to assert herself and chose self over selflessness, despite her daughter's opposition who doesn't want to hear the truth about her father.

A domestic crisis, breaking the photograph, spurs Ajji to find her voice. She gains the strength to defy and triumph over her artificial reality due, in part, to Priti “I have a feeling that she is with me now, giving me strength for the battle, urging me on to it" (376). At the end of the story, when Priti comes home from school and asks where Ajji is, Ajji's reply, "Here . . . I'm here," carries a great deal of symbolic importance. This simple assertion 
not only indicates a simple physical location, but it also reveals an emotional, psychological assertion of selfactualization and self-affirmation: for the first time in her life she IS. She has faced her sense of guilt in confronting Aarti and telling her the truth about her own life and overcomes her loss of face and defies the customs of her culture. In doing so, she acquires a sense of self-respect and "new" voice. She, like Esperanza, crosses a threshold into the unknown. Her voice here indicates a personal triumph, but it has universal implications. By finding and asserting her voice, Ajji has provided a role model for Priti and Aarti to follow in their own journey to find and assert their voices. Ajji may not have saved the world, but she has emerged from the pyre, a spiritually stronger character who has triumphed over her oppressor and broken the silence. Ajji's personal victory demonstrates once again-in the death and rebirth archetypical cyclethat from sublimation and imposed silence, individual voice and identity may emerge stronger and in defiance of cultural norms.

While the "room" for Ajji, the main character in Shahsi Deshpande's short story, symbolizes isolation, confinement, and an artificial reality, the room in the non-fiction memoir, Reading Lolita is Tehran by Azar Nafisi, symbolizes freedom, a place of "transgression" where Nafisi, a former university teacher, and seven of her students meet to be "transformed into [jewels] through the magic eye of fiction" (8). Nafisi's living room becomes a "protective cocoon" where the women, who are forced to meet in secret to read fiction forbidden by the regime in Iran (26), can discuss the relationship between fiction and reality (6).

Before meeting in this room to discuss works of fiction, all the women experienced a loss of voice. They all believed themselves to be totally irrelevant in their society. Even Nafisi, who organized the secret meetings, experiences many situations in which she feels as if she is "descending into an abyss or void" (167). Her feelings 